\title{
Do Renewable Energy Policies Can Decrease The Deaths From Outdoor and Indoor Air Pollution? Empirical Evidence From Latin American and Caribbean Countries
}

\section{Matheus Koengkan ( $\nabla$ matheuskoengkan@ua.pt)}

University of Aveiro Department of Economics Management Industrial Engineering and Tourism:

Universidade de Aveiro Departamento de Economia Gestao Engenharia Industrial e Turismo https://orcid.org/0000-0002-0062-4476

José Alberto Fuinhas

University of Coimbra Faculty of Economics: Universidade de Coimbra Faculdade de Economia

Emad Kazemzadeh

Ferdowsi University of Mashhad Faculty of Economics and Business Administration

Nooshin Karimi Alavijeh

Ferdowsi University of Mashhad Faculty of Economics and Business Administration

Saulo Jardim Araújo

Federal Fluminense University: Universidade Federal Fluminense

\section{Research Article}

Keywords: Air pollution death, Financial incentives, Fiscal incentives, Latin America and the Caribbean region, Renewable energy policies.

Posted Date: July 26th, 2021

DOI: https://doi.org/10.21203/rs.3.rs-653348/v1

License: (c) (i) This work is licensed under a Creative Commons Attribution 4.0 International License. Read Full License 


\section{Abstract}

This investigation analysed the effect of renewable energy incentive policies on deaths caused by outdoor and indoor air pollution in fifteen countries from Latin America and the Caribbean (LAC) region over the period from 1990 to 2017. The results from the Panel quantile model regression showed that in the $0.25,0.5$, and 0.75 quantiles, the variables carbon dioxide emissions, electricity consumption from new renewable energy sources economic instruments-fiscal/financial incentives policies to enable clean energy deployment, economic growth, and social globalisation reduces the air pollution deaths, while the variables electricity consumption from non-renewable energy sources, urbanisation, and economic globalisation encourages the increase of these deaths caused by outdoor and indoor air pollution in the LAC region.

\section{Introduction}

Air pollution is capable of causing damage not only to fauna and flora but also to people's health. Thus, air pollution is responsible for a significant death rate in some countries. In addition, adverse effects on the health of the population have also been observed in nations where the occurrence of air pollution is below the levels determined by legislation. Therefore, it can be seen through this scenario that even at lower levels, air pollution has the potential to cause severe respiratory and cardiovascular diseases (Dapper et al., 2016).

In this sense, the replacement of conventional sources of energy generation by renewable sources, in which the latter is usually driven by the use of economic instruments, such as tax incentive policies, is seen as a viable and efficient alternative for reducing the levels of atmospheric pollution, and consequently a reduction in mortality rates in several countries. Several investigations have been carried out in the last decades to analyze the relationship between the increased use of renewable energy sources and reduction in the mortality rate caused by air pollution, as is the case of studies conducted by Blackman \& Harrington (2000), Kim et al., (2011); Nordhaus (2007), and among others.

In view of this, the motivation of this study starts with the need to better understand the relationships between the death rate proved by air pollution and the economic instruments used to promote renewable energy sources. Understanding this relationship will provide advances in the literature to strengthen the global debate in favour of public policies that have significant influences on the death rate. Also, Latin American and Caribbean (LAC) countries were selected for this study, as it is a region: (1) rich in natural resources with sustainable energy potentials; (2) it has a structurally fragile health system, making it difficult to treat diseases caused by air pollution; (3) with high potential for economic growth, and therefore will need new energy sources in the future; (4) which has the potential to meet all future energy demands, through the installation of non-conventional renewable generation sources (Vergara et al. 2013). 
Therefore, this work has as an unprecedented contribution to the literature the fact of analyzing, through the quantile model via moments, the effect of economic instruments little studied in the literature, such as fiscal and financial incentive policies, in the promotion of renewable energy sources, and consequently, in the reduction of death rates caused by outdoor and indoor air pollution in the LAC region. This work also brings contributions in the sense of providing information capable of assisting the decision-making of economic policy-making agents in the LAC region, thus making it possible to direct resources to effective economic instruments concerning reducing the death rate.

The present study aims to analyze the impact of the use of economic instruments as a tool to encourage the deployment of renewable energy sources, and thus verify its relationship with the death rate caused by air pollution in fifteen countries from the LAC region in the period from 1990 to 2017.

This study is organised as follows. Section 2 presents the literature review regarding the effect of economic instruments-fiscal/financial incentives policies (feed-in tariffs/premiums, grants and subsidies, loans, tax relief, taxes, and user charges) to enable clean energy deployment on environmental degradation. Section 3 provides the Method and data approach. Section 4 presents the results and a brief discussion. Section 5 presents the conclusions and policy implications.

\section{Literature Review}

Rising Greenhouse Gas emissions have led to an increase in deaths from air pollution, and governments are trying to use different economic instruments to increase renewable energy use and reduce pollution. Among these, policies such as carbon taxes, tax incentives, subsidies, loans and tariffs have more benefits than other policies (Kim et al., 2011).

Blackman \& Harrington (2000) in a study examining the effectiveness of economic incentives on reducing industrial air pollution in developing countries stated that both design shortcomings and limitations in monitoring and implementation hinder the effectiveness of economic instruments in developing countries. Harring (2014) found in a study for the European Union that people in Nordic and Benelux countries consider the effectiveness of economic instruments to protect the environment to be effective, while people in southern and eastern Europe are less aware of this effectiveness. According to Stelling (2014), economic instruments are effective for the Swedish freight transport sector in the short term and until new techniques are implemented. Whereas, the study of the effectiveness of economic instruments for the development of photovoltaics (PV) and wind energy in the European Union (EU) by Li et al. (2017) showed that feed-in tariffs are more efficient than renewable portfolio standards (RPS) for photovoltaic (PV) development and wind energy development.

Other studies have examined the effectiveness of carbon taxation on environmental quality (e.g., Kim et al., 2011; Nordhaus, 2007; and Pearce, 1991). Lin \& Li (2011) in a study for 5 northern European countries stated that the carbon tax in Finland has a significant impact on $\mathrm{CO}_{2}$ reduction. Meanwhile, the effects of the carbon tax in Denmark, Sweden and the Netherlands are not significant. Nevertheless, in Norway, the 
rapid growth of energy products has significantly increased $\mathrm{CO}_{2}$ emissions in the oil drilling and natural gas sectors. Guo et al. (2014) in a study for China using the CGE model. The authors found that the average carbon tax significantly reduces carbon emissions and energy consumption of fossil fuels, but slightly slows down economic growth. However, high carbon taxes have a significant negative impact on the economy and social welfare. In addition, they found that carbon taxes improved the use of clean energy.

Vera \& Sauma (2015) in a study for the electricity sector of Chile during the period 2014-2024 stated that the carbon tax policy of $5 \$$ (per ton of carbon) reduces $\mathrm{CO}_{2}$ emissions by $1 \%$ per year. In a study for Greece during the period 1998-1998, Floros \& Vlachou (2005) stated that 50\$ (per ton of carbon) carbon tax leads to a significant reduction in direct and indirect $\mathrm{CO}_{2}$ emissions, but at a high cost to the economy imposes, while Bruvoll \& Larsen (2004) in their study for Norway using general equilibrium simulations during the period 1990-1999 stated that the carbon tax only helps to reduce greenhouse gas emissions by $2 \%$. Results of carbon tax incentive policies to reduce carbon emissions in air transport by Qiu et al. (2020) in China showed that incentive policies can encourage airlines to improve fuel consumption and emissions performance under appropriate conditions.

Liu et al. (2014) in their study, in addition to a carbon tax as an economic instrument. The authors used command-and-control (CAC) to reduce air pollution in China's iron and steel sector. The simulation results show that the carbon tax can control several pollutants, but the emission reduction rate is limited. While the command-and-control (CAC) has very good effects in controlling different pollutants separately. A number of other studies examined the effectiveness of the fuel tax and subsidies. Zimmer \& Koch (2017) in a study for Europe found that reforming fuel taxes could prevent significant amounts of air pollutants, while Davis \& Kilian (2009), in a study for the United States, states that a $10 \%$ increase in gasoline taxes reduces the $\mathrm{CO}_{2}$ emissions in the United States by $1.5 \%$. Xie et al. (2021) used China's clean energy vehicle subsidy policy, finding that these policies generally significantly improve urban air quality and, in the long run, lead to effective technological advances. Wang (2020) in another study for China stated that market-based policies and top-down policies reduce pollution.

Other studies used several economic instruments simultaneously to compare their effectiveness. Mao et al. (2012) using the CIMS model system, examined the effectiveness of economic instruments (carbon tax, energy tax, fuel tax, subsidized clean energy vehicles). They said energy tax and fuel tax policies had the greatest impact on reducing environmental pollution, while subsidies had the least impact. Jorgenson \& Wilcoxen (1993) evaluated the effect of three types of taxes (fossil fuels, VAT, and carbon taxes) on reducing carbon dioxide emissions in the United States. They found that carbon taxes could have a major impact on coal mining and achieve a certain reduction in $\mathrm{CO}_{2}$ with minimal impact on the economy. The energy tax is almost the same as the carbon tax but has a slightly smaller impact on coal mining and a slightly higher overall cost. In contrast, VAT has a much smaller effect on reducing coal mining but has a greater impact on the economy as a whole. Cao et al., (2008) In a study for the Chinese electricity sector, they simulated three environmental tax policies (production tax, fuel tax, and carbon tax) using a top- 
down recursive dynamic CGE model (computable general equilibrium). The results suggest that the preferred policy for China is fuel tax or carbon tax at the national level. Shmelev \& Speck (2018) stated that the carbon tax does not significantly reduce $\mathrm{CO}_{2}$ emissions in Sweden, while the energy tax for coal and liquefied petroleum gas has been statistically significant. And that, renewable energy (excluding hydraulic) has not been statistically significant in reducing $\mathrm{CO}_{2}$ emissions.

Indeed, a number of other studies have examined the role of financial instruments in the environment. Katircioglu \& Katircioglu (2018) in a study to investigate the role of fiscal policies on environmental degradation in Turkey between 1960-2013 found that fiscal policies reduce carbon dioxide emissions. Kosonen \& Nicodème (2009) stated that taxes and other types of financial instruments in EU countries can complement each other effectively to achieve an environmental goal. Postula \& Radecka-Moroz (2020) in examining the effectiveness of EU member states tax policies stated that in addition to the type of financial instruments, they must also consider the impact of the time dimension, otherwise the effectiveness of these policies on the environment will be very limited. López \& Palacios (2014) in their study of the role of fiscal policies and energy taxes on environmental quality in the 12 richest European countries during the period 1995-2008 concluded that fiscal policies significantly reduced the concentration of sulfur dioxide and ozone While the energy tax reduces the concentration of nitrogen dioxide but has no effect on ozone and sulfur dioxide. Ike et al. (2020) in a study for Thailand, stated that a $1 \%$ increase in fiscal policy caused a $6.5 \%$ decrease in $\mathrm{CO}_{2}$ emissions from natural gas, $0.2 \%$ from oil derivatives, and a $0.2 \%$ increase from solid fuels (coal). Droste et al. (2018) confirmed the impact of financial incentives on environmental protection in Europe.

In contrast, some studies have shown that fiscal policy instruments either have little impact on the environment or cause more environmental degradation in the long run. Ring (2002) in a study for Germany found that these incentives are only effective in the short term. The results of Halkos \& Paizanos (2016) for the United States using the var model during the period 1973-2013 showed that the implementation of expansionary finance costs has a slight effect on the emission source. Cao et al., (2021) using a spatial panel model. The authors stated that although the implementation of ecological fiscal policies stimulates local governments' efforts to improve the quality of the environment, but these policies do not improve the environment, while Yuelan et al. (2019) in a study for China during the period 1980 to 2016, they found that fiscal policy instruments significantly increase environmental degradation in the long run.

As can be seen in previous studies, one or more different economic instruments have been used to evaluate their impact on the environment in different regions and countries. But so far no study has been done on the LAC region. And that in this study, a set of instruments such as (fiscal incentive policies, tariffs, taxes, loans, subsidies, feed-in tariffs, premiums, grants) is considered as an indicator for economic instruments. Another distinguishing feature of this study is investigating the effects of economic instruments on air pollution death rates, which has not been addressed in previous studies. In the next section, we will present the method and data that will be used to realise this empirical investigation. 


\section{Method And Data}

In this section, we will show the method approach and data/variables that were will be used in this empirical investigation.

\subsection{Method}

As mentioned before, this subsection will show the methodology that this empirical investigation will use. The Panel quantile model approach that developed by Machado \& Silva (2019). Then, this method has several advantages that were highlight by Koengkan et al. (2021a), for example (i) allows for the estimation of conditional quantiles using panel data in the presence of individual effects; (ii) allows to provide information on how the regressor affects the entire conditional distribution; (iii) allows to estimate in the presence of cross-section dependence and with endogenous variables; and (iv) this method is based on the moment conditions that find the conditional means under exogeneity. Besides, it can find the same structural quantile function. For these advantages that this empirical investigation opted to use this method.

Therefore, after a brief explanation of the main method approach that will use, it is necessary to show the equation of the Panel quantile model, see Eq. (1), below.

$$
\lambda_{i t}=\lambda_{i}+e_{i t}^{\prime} \beta+\left(\omega_{i}+Z_{i t}^{\prime} \gamma\right) \mu_{i t},
$$

where $\lambda_{i t}, e_{i t}^{\prime}$ from a panel of $N$ individuals $i=1, \ldots, N$ over $T$ time-periods with $P\left\{\omega_{i}+Z_{i t}^{\prime} \gamma>0\right\}=1$.

Indeed, before the realisation of the Panel quantile model regression, it is necessary to carry out the preliminary tests. The same occurs after the model regressions, where it is necessary to compute the post-estimation tests. Table 1, below evidence the preliminary and post-estimation test that will be used in this empirical investigation. 
Table 1

Preliminary and Post-estimation tests for the Panel quantile model

\section{Preliminary tests}

\section{Tests}

Bias-corrected LM-based test

(Born \& Breitung, 2015)

Variance inflation factor (VIF)

(Belsley et al., 1980)

Cross-section dependence

(CSD) (Pesaran, 2004)

Panel unit root test (CIPS)

(Pesaran, 2007)

Hausman test

\section{Objective}

To find the presence of serial correlation in the fixed-effects panel model.

To find the presence of multicollinearity between the variables.

To find the presence of cross-sectional dependence (CSD) in the panel data.

To find the presence of unit roots.

To find the presence of heterogeneity, i.e. whether the panel has random effects (RE) or fixed effects (FE).

\section{Postestimation tests}

Wald test (Agresti, 1990)

To find the global significance of the estimated models.

Notes: This table was created by the authors.

All model estimations and testing procedures will be accomplished using Stata 16.0, and all Stata' commands that were used in this empirical analysis will be provided in the notes of tables to allow their reapplication. In the next subsection, we will show the data/variables that will be used in this investigation.

\subsection{Data}

In this subsection, we will present the data/variables that will be utilised in this study. In this context, fifteen countries from the LAC region were selected to realise this empirical analysis. For example, Argentina, Bolivia, Brazil, Chile, Colombia, Costa Rica, Dominican Republic, Ecuador, Guatemala, Mexico, Panama, Paraguay, Peru, Uruguay, and Venezuela (RB). This study opted to use the period of data from 1990 to 2017 , due to the disponibility of data. Therefore, the variables that will be used and their summary statistic are shown in Table 2 , below. 
Table 2

Variables' description and summary statistics

\section{Variables' description}

\section{Variable Definition}

DRAP Death rates from air pollution measure the number of deaths per 100,000 population from both outdoor and indoor air pollution.

$\mathrm{CO}_{2}$

Carbon dioxide emissions in kilotons $(\mathrm{Kt})$ per capita from the burning of fossil fuels and the manufacture of cement. This variable also includes carbon dioxide produced during the consumption of solid, liquid and gas fuels and gas flaring.

REC

Electricity consumption from new renewable energy sources (e.g., biomass, solar, photovoltaic, wind, wave, and waster) in (kWh) per capita.

EIP

Economic instruments-fiscal/financial incentives policies to enable clean energy deployment. The economic instruments include feed-in tariffs/premiums, grants and subsidies, loans, tax relief, taxes, and user charges. This variable was built in accumulated form, where each policy that was created is represented by (1) accumulated over other policies throughout its useful life or end (e.g. 1, 1, 2, 2, 2, 3,3).

FOC Electricity consumption from non-renewable energy sources (e.g., Oil, gas, and coal) in (kWh) per capita.

GDP Gross Domestic Production in constant local currency unity (LCU) and expressed per capita.

URB Urban population rate, which refers to people living in urban areas as defined by national statistical offices. This variable is a proxy of urbanisation.

KOFSoGI Social Globalisation index in the de facto that measure the interpersonal, information, and cultural globalisation.

KOFEcGI Economic Globalisation index in the de facto that measure the trade and financial globalisation. Trade globalisation is determined based on trade in goods and services, and financial globalisation includes foreign investment in various categories.

\section{Source}

Our World in Data (2021)

World Bank Open Data (2021)

World Bank Open

Data (2021)

International Energy Agency (2021)
World Bank Open

Data (2021)

World Bank Open

Data (2021)

World Bank Open

Data (2021)

KOF Globalisation Index (2021)

KOF Globalisation Index (2021)

\section{Summary statistics}

\begin{tabular}{|llllll|}
\hline Variables & Obs. & Mean & Std. Dev & Min & Max \\
\hline DRAP & 448 & 0.6264 & 0.6290 & -0.7084 & 2.0414 \\
\hline $\mathrm{CO}_{2}$ & 448 & 10.3819 & 0.7230 & 9.0951 & 12.0487 \\
\hline REC & 448 & 0.8165 & 0.7767 & 0.0000 & 2.7080 \\
\hline EIP & 448 & 11.2117 & 0.8426 & 8.6280 & 12.6843 \\
\hline FOC & 448 & 11.2087 & 3.0597 & 7.2408 & 17.1658 \\
\hline
\end{tabular}




\begin{tabular}{|llllll|}
\hline \multicolumn{4}{|l|}{ Variables' description } & \multicolumn{3}{l|}{} \\
\hline GDP & 448 & 4.2469 & 0.2019 & 3.7374 & 4.5642 \\
\hline URB & 448 & 0.6264 & 0.6290 & -0.7084 & 2.0414 \\
\hline KOFSoGI & 448 & 3.9936 & 0.2259 & 3.3184 & 4.4012 \\
\hline KOFEcGI & 448 & 3.8869 & 0.2378 & 3.2576 & 4.4117 \\
\hline $\begin{array}{l}\text { Notes: The Stata command sum was used; All variables in this model were transformed in the natural } \\
\text { logarithms; Obs. denotes the number of observations in the model; Std.-Dev. denotes the Standard } \\
\text { Deviation; Min. and Max. denote Minimum and Maximum, respectively. }\end{array}$ \\
\hline
\end{tabular}

All variables that were used align with the existing literature. It is, worth remembering that the variables (e.g., $\mathrm{CO}_{2}$, REC, FOC, GDP, URB, KOFSoGI, and KOFEcGI) are already used by the literature to explain the increase or decrease of air pollution death rate. Nevertheless, only the variable EIP, is explored by the literature. This makes this study innovative if compared with others that approach a similar topic. Moreover, all variables in Table 2 are in natural logarithms, and in this analysis, we decided to use the variables in per capita values (e.g., $\mathrm{CO}_{2}, \mathrm{REC}, \mathrm{FOC}$, and GDP). Indeed, the use of per capita values allows us to mitigate the disparities between the variables caused by population growth over time in the crosses, as cited by Koengkan et al. (2021a).

In this subsection, we approached the group of countries and the variables that will be used in our study. In the next section, we demonstrate the empirical results and discussions.

\section{Empirical Results And Discussions}

In this section we will present the results from the preliminary and post-estimation tests, the main model and the robustness check, as well as the possible explanation for the impacts that were found. In this context, the results from the preliminary tests indicate the presence of serial correlation up to the secondorder, where the null hypothesis of Bias-corrected LM-based test can be rejected (see Table 1A in the Appendix); The presence of low-multicollinearity and cross-section dependence between the variables of the model (see Table 2A in the Appendix), and the variables being on the borderline between the I(0) and I(1) orders of integration (see Table 3A in the Appendix). Moreover, the preliminary tests indicate the presence of fixed effects was found, where the null hypothesis of the Hausman test can be rejected (see Table 4A in the Appendix).

After to realisation of preliminary tests, it is needed to carry out the Panel quantile model regression. The $\mathbf{0 . 2 5}, \mathbf{0 . 5}$, and $\mathbf{0 . 7 5}$ quantiles were respectively calculated. These quantiles were used to simplify the exhibition of empirical results. Table 3 below, shows the results from the Panel quantile model regression. 
Table 3

Panel quantile model and post-estimation test

\begin{tabular}{|c|c|c|c|c|c|c|}
\hline \multirow[t]{3}{*}{ Independent variables } & \multicolumn{6}{|c|}{ Dependent variable (DRAP) } \\
\hline & \multicolumn{6}{|c|}{ Quantiles regression at } \\
\hline & $0.25 Q$ & & $0.5 \mathrm{Q}$ & & $0.75 Q$ & \\
\hline $\mathrm{CO}_{2}$ & -0.1705 & ** & -0.1501 & $\star \star \star *$ & -0.1289 & ** \\
\hline REC & -0.1231 & $\star \star \star *$ & -0.1467 & $\star \star \star ~$ & -0.1703 & $\star \star \star$ \\
\hline EIP & -0.0297 & ** & -0.0259 & $\star \star \star \star ~$ & -0.0220 & ** \\
\hline FOC & 0.3930 & $\star \star \star \star ~$ & 0.3434 & $\star \star \star \star ~$ & 0.2919 & $\star \star \star ~$ \\
\hline GDP & -0.3105 & $\star \star \star *$ & -0.2358 & 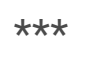 & -0.1582 & ** \\
\hline URB & 0.6540 & $\star \star \star *$ & 0.6810 & $\star \star \star *$ & 0.7090 & *** \\
\hline KOFSOGI & -0.2847 & $\star \star \star$ & -0.2534 & $\star \star \star *$ & -0.2208 & *** \\
\hline KOFEcGI & 0.1456 & $\star \star \star$ & 0.1043 & $\star \star \star$ & 0.0615 & * \\
\hline Obs & 448 & & 448 & & 448 & \\
\hline \multicolumn{7}{|c|}{ Postestimation test for the QvM model } \\
\hline F / Wald test & Chi2(8) $=104.29$ & $\star \star \star$ & Chi2(8) $=174.64$ & 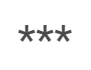 & Chi2(8) $=105.50$ & 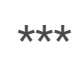 \\
\hline
\end{tabular}

The results from the Panel quantile model regression show that in the $\mathbf{0 . 2 5}, \mathbf{0 . 5}$, and $\mathbf{0 . 7 5}$ quantiles, the variables Carbon dioxide emissions $\left(\mathrm{CO}_{2}\right)$, Electricity consumption from new renewable energy sources (REC), Economic instruments-fiscal/financial incentives policies to enable clean energy deployment (EIP), Economic growth (GDP), and Social Globalisation (KOFSoGI) reduces the air pollution deaths (DRAP), while the variables Electricity consumption from non-renewable energy sources (FOC), urbanisation (URB), and Economic globalisation (KOFEcGI) encourages the increase of these deaths in the LAC region. Moreover, the results from the post-estimation test for the Panel quantile model indicates that the model estimator that this study choose is adequate to perform this analysis.

The next step after the realisation of the main model regression is the verification of the robustness of the results. To this end, we added variables, dummies, in the Panel quantile model regression (see Table 4, below). 
Table 4

Panel quantile model (with dummy variables) and post-estimation test

\begin{tabular}{|c|c|c|c|c|c|c|}
\hline \multirow[t]{3}{*}{ Independent variables } & \multicolumn{6}{|c|}{ Dependent variable (DRAP) } \\
\hline & \multicolumn{6}{|c|}{ Quantiles regression at } \\
\hline & $0.25 Q$ & & $0.5 \mathrm{Q}$ & & $0.75 Q$ & \\
\hline IDPARAGUAY_2010 & 0.2105 & $\star \star \star ~$ & 0.1578 & $\star \star \star ~$ & 0.1047 & 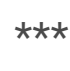 \\
\hline IDPARAGUAY_2011 & 0.1688 & 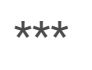 & 0.1187 & $\star \star \star$ & 0.0681 & *** \\
\hline $\mathrm{CO}_{2}$ & -0.1655 & ** & -0.1474 & $\star \star \star *$ & -0.1290 & ** \\
\hline REC & -0.1255 & 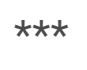 & -0.1480 & 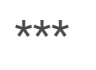 & -0.1708 & *** \\
\hline EIP & -0.0301 & ** & -0.0261 & 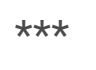 & -0.0222 & * \\
\hline FOC & 0.3899 & $\star \star * *$ & 03403 & $\star \star \star ~$ & 0.2902 & $\star \star \star *$ \\
\hline GDP & -0.3022 & $\star \star \star *$ & -0.2292 & 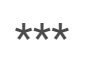 & -0.1555 & ** \\
\hline URB & 0.6468 & $\star \star \star *$ & 0.6779 & $\star \star \star ~$ & 0.7093 & $\star \star \star *$ \\
\hline KOFSOGI & -0.2922 & 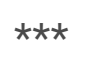 & -0.2587 & $\star \star \star ~$ & -0.2249 & $* \star \star$ \\
\hline KOFEcGI & 0.1493 & 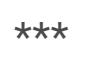 & 0.1077 & $\star \star \star *$ & 0.0658 & \\
\hline Obs & 448 & & 448 & & 448 & \\
\hline \multicolumn{7}{|c|}{ Post-estimation test for the Panel quantile model } \\
\hline F / Wald test & Chi2(8) $=107.90$ & 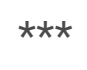 & Chi2(8) = 178.56 & 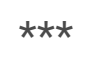 & $\operatorname{Chi} 2(8)=107.30$ & 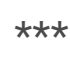 \\
\hline
\end{tabular}

To verify the robustness of the Panel quantile model regression that was carried out before, this investigation opted to add in the model regression dummy variables. These dummies variables represent possible shocks (e.g., economic, pollical, and social) that some LAC countries passed. However, if not considered it, could have produce inaccurate results, which could lead to misinterpretations. Therefore, dummy variables that were added to the model regression are IDPARAGUAY_2010 (Paraguay, the year 2010), and IDPARAGUAY_2011 (Paraguay, the year 2011). These two dummies represent a peak in Paraguay's GDP, wherein in 2010 the country registered a growth of $13 \%$, while in 2011, was registered a growth of $4.3 \%$ (World Bank Open Data, 2021). Indeed, this rapid growth in economic activity in Paraguay, affected consumer behaviour, industrial production, the consumption of energy, and consequently the air pollution. 
Therefore, the results from the Panel quantile model with dummy variables, indicate that in the $\mathbf{0 . 2 5} \mathbf{0 . 5}$, and $\mathbf{0 . 7 5}$, quantiles the variables Carbon dioxide emissions $\left(\mathrm{CO}_{2}\right)$, Electricity consumption from new renewable energy sources (REC), Economic instruments-fiscal/financial incentives policies to enable clean energy deployment (EIP), Economic growth (GDP), and Social Globalisation (KOFSoGI) reduces the air pollution deaths (DRAP), while the variables Electricity consumption from non-renewable energy sources (FOC), urbanisation (URB), encourages increase the of these deaths in the LAC region. Moreover, the Economic globalisation (KOFEcGI) in $\mathbf{0 . 2 5}$, and $\mathbf{0 . 5}$, quantiles, also increase this problem.

The dummy variables are statistically significant at $1 \%$ levels, indicating that the approach of this investigation used, such as to add dummy variables in the model regression is the most correct. The results from the post-estimation test for the Panel quantile model indicates that the model estimator that this study choose is adequate to perform this analysis. Finally, the results obtained from the model regression confirms that the results of this investigation are robust and reliable even in the presence of chocks. Indeed, to summarise the effect of independent variables on dependent ones, ones created in Fig. 1, below. This figure was based on the results of the Panel quantile model.

After to found that the Carbon dioxide emissions $\left(\mathrm{CO}_{2}\right)$, Electricity consumption from new renewable energy sources (REC), Economic instruments-fiscal/financial incentives policies to enable clean energy deployment (EIP), Economic growth (GDP), and Social Globalisation (KOFSoGI) reduces the air pollution deaths (DRAP), while the variables Electricity consumption from non-renewable energy sources (FOC), urbanisation (URB), and Economic globalisation (KOFEcGI) encourages the increase of these deaths caused by the air pollution in the LAC region, we raise the following question. What are the explanations

\section{for these effects?}

As shown in Fig. 1, the effect of carbon dioxide emissions on air pollution deaths rates in the countries under study is negative. The negative signal of $\mathrm{CO}_{2}$ emissions could seem atypical but reflect the substitution of more dangerous gases by activities less aggressive for humans, but there are $\mathrm{CO}_{2}$ emitters (e.g., Koengkan et al., 2021a). Fuinhas et al. (2017) that studied the effect of renewable energy policies on $\mathrm{CO}_{2}$ emissions in the LAC region, identify that the renewable energy policies in the region encourages the process of the energy transition by consumption of renewable energy, reduces the consumption of fossil fuels, and consequently reduces the emissions of $\mathrm{CO}_{2}$. This reduction in $\mathrm{CO}_{2}$ emissions reflects in the reduction of air pollution deaths. Moreover, evidence that the energy transition reduces the consumption of non-renewable energy in the LAC region was found by Koengkan et al. (2021b). According to the author, renewable energy consumption that is a proxy of the energy transition reduces the consumption of fossil fuels. The same authors also add that the reduction of non-renewable energy sources by the consumption of renewable energy sources is possible due to the presence of effective renewable energy policies that encourages the development, investment, and consumption of green energy in the region.

This explanation was confirmed using the Pooled OLS model regression. Table 5 below, shows the capacity of economic instruments-fiscal/financial incentives policies to encourages the consumption of 
renewable energy sources. Moreover, the results also indicate that the consumption of renewable energy and economic instruments-fiscal/financial incentives policies decrease the consumption of fossil fuels and $\mathrm{CO}_{2}$ emissions in the $\mathrm{LAC}$ region. 
Table 5

Pooled OLS model regression and post-estimation test

\begin{tabular}{|c|c|c|}
\hline Independent variables & Dependent variable (REC) & \\
\hline EIP & 0.0958 & ** \\
\hline GDP & 0.0898 & $\star \star \star *$ \\
\hline URB & 1.1756 & *** \\
\hline Constant & 4.3257 & 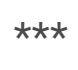 \\
\hline Obs & 448 & \\
\hline \multicolumn{3}{|c|}{ Postestimation test for the Pooled OLS model } \\
\hline F / Wald test & $F(3,444)=60.97$ & *** \\
\hline Independent variables & Dependent variable (FOC) & \\
\hline REC & -0.0677 & *** \\
\hline EIP & -0.2695 & 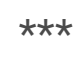 \\
\hline GDP & -0.0622 & *** \\
\hline URB & 2.5894 & 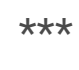 \\
\hline KOFSOGI & -2.1868 & 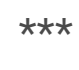 \\
\hline KOFEcGI & 0.2759 & *** \\
\hline Constant & -7.1211 & $\star \star \star *$ \\
\hline Trend & -0.0075 & 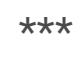 \\
\hline Obs & 448 & \\
\hline \multicolumn{3}{|c|}{ Post-estimation test for the Pooled OLS model } \\
\hline F / Wald test & $F(6,440)=405.86$ & *** \\
\hline Independent variables & Dependent variable $\left(\mathrm{CO}_{2}\right)$ & \\
\hline REC & -0.2733 & $* * *$ \\
\hline EIP & -0.0735 & $\star * \star$ \\
\hline GDP & -0.0113 & *** \\
\hline URB & 0.1753 & * \\
\hline FOC & 0.7019 & $* * *$ \\
\hline Constant & -4.9631 & $\star \star \star *$ \\
\hline
\end{tabular}




\section{Obs}

448

\section{Postestimation test for the Pooled OLS model}

F / Wald test

$F(5,442)=647.92$

$\star \star \star$

Notes: The Stata commands reg and testparm were used $\star \star \star, \star \star *$, denotes statistically significant at $1 \%, 5 \%$, and $10 \%$ level.

According to Table 3, the effect of electricity consumption from new renewable energy sources on DRAP in all quantiles is negative and significant. In other words, with a $1 \%$ increase in REC, the air pollution deaths decrease by $0.12 \%$ at 0.25 th quantile, and higher quantiles, the negative effect of REC on air pollution deaths increases. It can be said that the use of renewable energy sources to generate electricity reduces the emission of carbon dioxide and other pollutants, which can ultimately reduce air pollution deaths. This finding is consistent with Kharecha \& Hansen (2013), Hanif (2018), Taghizadeh-Hesary \& Taghizadeh-Hesary (2020), and Koengkan et al. (2021a).

The economic instruments-fiscal/financial incentives policies to enable clean energy deployment has a negative and significant effect on air pollution deaths rate in the LAC region. As shown in Table 3, with increasing quantile, the impact of this factor on air pollution deaths is decreased. In other words, the impact of EIP in countries that account for $25 \%$ high of air pollution deaths is lower than those at the lowest levels. In other words, the government's financial incentives policies to enable clean energy deployment cause industries and companies in the countries under study to use clean and environmentally friendly technologies, thus this matter leading to a reduction in pollutants and, consequently, a reduction in air pollution deaths.

The impact of electricity consumption from non-renewable energy sources on air pollution deaths is positive and significant. Electricity consumption from non-renewable energy sources such as oil and gas emits pollutants such as $\mathrm{CO}_{2}, \mathrm{SO}_{2}$, and $\mathrm{NO}_{x}$ into the air and increases air pollution deaths. This finding is consistent with Mukhopadhyay \& Forssell (2005), Machol \& Rizk (2013), Lelieveld et al. (2019), Marais et al. (2019), and Rasoulinezhad et al. (2020).

According to the results, the impact of GDP on air pollution deaths is negative and significant. It can be argued that increasing GDP and economic growth may be an important tool for improving countries' infrastructure that reduces mortality. Zhang et al. (2001), Janssen et al. (2006), and Hanif (2018) confirm a negative relationship between GDP and deaths. On the other hand, other studies such as Chaabouni et al. (2016) and Rasoulinezhad et al. (2020), have shown that the impact of GDP on mortality is positive. In fact, in these studies, economic growth may lead to the emission of pollutants due to the need to use fossil fuels, which endangers human health. Indeed, evidence that the Latin American and Caribbean countries are in the process of decarbonization is found in Table 5, where was found that economic 
growth reduces emissions. This result is related to the capacity of economic growth to increase the consumption of renewable energy sources.

According to Table 3, urbanisation has a positive and significant effect on air pollution deaths in all quantiles. Accordingly, a $1 \%$ increase in urbanisation led to a $0.65 \%$ increase in air pollution deaths in the 25th quantile. An increase in urbanisation means an increase in population, and an increase in population leads to carbon dioxide emissions (e.g., Mansoor \& Sultana, 2018; Salehnia et al., 2020; Dogan \& Inglesi-Lotz, 2020). Therefore, $\mathrm{CO}_{2}$ emissions increase air pollution deaths. This finding confirms that found by Rumana et al. (2014), Liu et al. (2017a), Chen et al. (2017), and Liu et al. (2017b). This explanation is confirmed with results that were pointed in Table 5 above, where the urbanisation process increases the consumption of fossil fuels and $\mathrm{CO}_{2}$ emissions.

According to Fig. 1, there is an inverse relationship between the Social Globalisation index and the air pollution deaths, so that with the increase of KOFSoGI, the air pollution deaths in the studied countries decreases. In other words, social globalisation, through information and cultural links, connects the people of the LAC region countries. Social globalisation enables countries to access new information. New knowledge help reduces energy consumption in production processes, which can improve environmental quality and reduce air pollution deaths (e.g., Shahbaz et al., 2018). Indeed, this explanation is confirmed with results that were pointed in Table 5 above, where social globalisation reduce the consumption of fossil fuels.

Finally, according to the research findings, the Economic Globalisation index leads to an increase in air pollution deaths in the countries under study. As economic globalisation connects the economy through trade in goods and services, foreign investment, and financial activities, the expansion of the global economy leads to more energy consumption, resulting in more carbon dioxide emissions, and endangers people's health (e.g., Shahbaz et al. 2015 and Shahbaz et al., 2018). This outcome is linin e with studies in the literature such as Kan (2014). This explanation is confirmed with results that were pointed in Table 5 abover, where the economic globalisation increases the consumption of fossil fuels.

As mentioned before, this section showed the results and their possible explanations for the results that were found in our empirical investigation. The next section, will present the conclusions and possible policy implications.

\section{Conclusions And Policy Implications}

A panel quantile model was used to analyse the deployment of renewables sources of energy on the death rate provoked by air pollution in fifteen countries from the LAC region over the period from 1990 to 2017. Given the complexity of the link between renewables and air pollution, the relationship requires a broad model that must include quite a few control variables. Those variables were identified based on the literature and the phenomenon's economic and social nature under analysis. Thus, to explain the death $\mathrm{c}$ were used: (i) carbon dioxide emissions; (ii) electricity consumption from new renewable energy sources; 
(iii) economic instruments-fiscal/financial incentives policies to enable clean energy deployment; (iv) electricity consumption from non-renewable energy sources; (v) Gross Domestic Production; (vi) urban population rate; (vii) social globalisation index (de facto); and (viii) economic globalisation index (de facto).

The results confirm the nonlinear relationship between the explanatory variables and the explained variable. Provided that deaths rates from air pollution in the LAC region are mainly associated with huge urban centres, much of the analysis applies to that reality. Indeed, the quantiles evolve in a way compatible with the perceived status quo of big cities of The LAC region.

The variables that reduce the deaths rates from air pollution are carbon dioxide emissions, electricity consumption from new renewable energy sources, economic instruments-fiscal/financial incentives policies to enable clean energy deployment, Gross Domestic Production, and the social globalisation index (de facto). Except for electricity consumption from new renewable energy sources, these variables decrease their effect on deaths rates from air pollution as the quantiles increase.

The variables that aggravate the deaths rates from air pollution are electricity consumption from nonrenewable energy sources, urban population rate, and economic globalisation index (de facto). Except for the urban population rate, these variables decrease their effect on deaths rates from air pollution as the quantiles increase.

The specific contribution of this research for literature end policymaking and makes it innovative is an analysis of the variable economic instruments-fiscal/financial incentives policies to enable clean energy deployment that is few studied by the literature. As expectable economic instruments-fiscal/financial incentives policies (feed-in tariffs/premiums, grants and subsidies, loans, tax relief, taxes, and user charges) to enable clean energy deployment, contribute to decrease deaths rates from air pollution. Their effect is more intense for lower quantiles supporting that intervention is more effective when health problems are not as severe.

A more subtle effect detected in this research is the negative signal of $\mathrm{CO}_{2}$ emission on the deaths rates from air pollution. The explanation for this result that could seem atypical indeed is the reflex of two leading causes. First, it reflects the substitution of more dangerous gases to activities less aggressive for humans, but there are $\mathrm{CO}_{2}$ emitters (Koengkan et al., 2021a). Second, it is also consistent with the switch of huge pollution activities from big cities to other locations less demanding of health standards, political pressure that has contributed to the tertiarisation of economic activities in big cities.

Another impressive result is the effect of globalisation on the deaths rates from air pollution. Here was found an opposite influence depending on whether globalisation is social or economic. In both cases, the effect is more pronounced in lower quantiles. The stimulation of interpersonal, informational, and cultural globalisation reduces the deaths rates from air pollution. In contrast, the trade in goods and services and financial and foreign investment globalisation go in a way that aggravates deaths rates from air pollution. 
From a policymaking perspective, the combat to mitigate deaths rates from air pollution should intensify the transition from fossil fuels energy to renewable sources that can be magnified by recurring to economic instruments-fiscal/financial incentives policies to enable clean energy deployment. The policymakers should promote the transfer of economic activities that are huge polluters to places less populated. It can take advantage of increasing industrial efficiency that demands less and less employment. Policymakers should actively take advantage of social globalisation benefits and limit the hampers made by economic globalisation. Finally, policymakers should stimulate economic growth because this allows access to health services and helps finance the transition to a more unpolluted environment.

\section{Declarations}

\section{Ethical Approval}

This article does not contain any studies with human participants performed by any of the authors.

\section{Authors Contributions}

Matheus Koengkan: Conceptualisation, Methodology, Writing - Original draft preparation, Supervision, Validation, Data curation, Investigation, Formal analysis, Visualisation.

José Alberto Fuinhas: Conclusions, Reviewing and Editing.

Emad Kazemzadeh: Literature review.

Nooshin Karimi Alavijeh: Discussions.

Saulo Jardim de Araújo: Introduction.

\section{Conflict of Interest Statement}

Matheus Koengkan declares that he has no conflict of interest. José Alberto Fuinhas declares that he has no conflict of interest. Emad Kazemzadeh declares that he has no conflict of interest. Nooshin Karimi Alavijeh declares that he has no conflict of interest. Saulo Jardim de Araújo declares that he has no conflict of interest.

\section{Funding}

Research supported by CeBER, R\&D unit funded by national funds through FCT - Fundação para a Ciência e a Tecnologia, I.P., project UIDB/05037/2020.

\section{Availability of data and material}

Data and material will be available when asked for. 


\section{Code availability (software application or custom code)}

Codes will be available when asked for.

\section{Consent to participate}

All authors consent to participate in this investigation.

\section{Consent for publication}

All authors consent to publication this investigation.

\section{References}

1. Agresti A (1990) Categorical Data Analysis. John Wiley and Sons, New York. ISBN 0-471-36093-7

2. Belsley DA, Kuh E, Welsch RE (1980) Regression Diagnostics: Identifying Influential Data and Sources of Collinearity. New York: Wiley.10.1002/0471725153

3. Blackman A, Harrington W (2000) The use of economic incentives in developing countries: Lessons from international experience with industrial air pollution. The Journal of Environment Development 9(1):5-44. https://doi.org/10.1177/107049650000900102

4. Born B, Breitung J (2015) Testing for Serial Correlation in Fixed-Effects Panel Data Models. Econom Rev 35(7):1290-1316. https://doi.org/10.1080/07474938.2014.976524

5. Breusch TS, Pagan AR (1980) The Lagrange multiplier test and its applications to model specification in econometrics. The Review of Economic Studies 47(1):239-253. https://www.jstor.org/stable/pdf/2297111.pdf

6. Bruvoll A, Larsen BM (2004) Greenhouse gas emissions in Norway: do carbon taxes work? Energy Policy, 32(4), 493-505. https://doi.org/410.1016/S0301-4215(1003)00151-00154

7. Cao H, Qi Y, Chen J, Shao S, Lin S (2021) Incentive and coordination: Ecological fiscal transfers' effects on eco-environmental quality. Environmental impact assessment review, 87, 106518. https://doi.org/106510.101016/j.eiar.102020.106518

8. Cao J, Ho M, Jorgenson D (2008) "co-benefits" of greenhouse gas mitigation policies in china: an integrated top-down and bottom-up modeling analysis. Retrieved from URL: http://www.rff.org/RFF/documents/EfD-DP-08-10.pdf

9. Chaabouni S, Zghidi N, Mbarek MB (2016) On the causal dynamics between CO2 emissions, health expenditures and economic growth. Sustainable cities society 22:184-191. https://doi.org/10.1016/j.scs.2016.02.001

10. Chen W, Zheng R, Zhang S, Zeng H, Zuo T, Xia C, He J (2017) Cancer incidence and mortality in China in 2013: an analysis based on urbanization level. Chin J Cancer Res 29(1):1. https://doi.org/10.21147/j.issn.1000-9604.2017.01.01 
11. Dapper SN, Spohr C, Zanini RR (2016) Poluição do ar como fator de risco para a saúde: uma revisão sistemática no estado de São Paulo. Estudos Avançados 86:83-97.

http://dx.doi.org/10.1590/S0103-40142016.00100006

12. Davis LW, Kilian L (2009) Estimating the effect of a gasoline tax on carbon emissions (0898-2937)

13. Dogan E, Inglesi-Lotz R (2020) The impact of economic structure to the environmental Kuznets curve (EKC) hypothesis: evidence from European countries. Environ Sci Pollut Res, 1-8. https://doi.org/10.1007/s11356-020-07878-2

14. Droste N, Ring I, Santos R, Kettunen M (2018) Ecological fiscal transfers in Europe-Evidence-based design options for a transnational scheme. Ecological Economics, 147, 373-382. https://doi.org/310.1016/j.ecolecon.2018.1001.1031

15. Floros N, Vlachou A (2005) Energy demand and energy-related CO2 emissions in Greek manufacturing: Assessing the impact of a carbon tax. Energy Economics, 27(3), 387-413. https://doi.org/310.1016/j.eneco.2004.1012.1006

16. Fuinhas JA, Marques AC, Koengkan M (2017) Are renewable energy policies upsetting carbon dioxide emissions? The case of Latin America countries. Environ Sci Pollut Res 24(17):15044-15054. 10.1007/s11356-017-9109-z

17. Granger CWJ (1981) Some Properties of Time Series Data and Their Use in Econometric Model Specification. J Econ 28:121-130

18. Greene W (2002) Econometric Analysis. Prentice-Hall, Saddle River

19. Guo Z, Zhang X, Zheng Y, Rao R (2014) Exploring the impacts of a carbon tax on the Chinese economy using a CGE model with a detailed disaggregation of energy sectors. Energy Economics, 45, 455-462. https://doi.org/410.1016/j.eneco.2014.1008.1016

20. Halkos GE, Paizanos E (2016) The effects of fiscal policy on CO2 emissions: evidence from the USA. Energy Policy, 88, 317-328. https://doi.org/310.1016/j.enpol.2015.1010.1035

21. Hanif I (2018) Energy consumption habits and human health nexus in Sub-Saharan Africa. Environ Sci Pollut Res 25(22):21701-21712. https://doi.org/10.1007/s11356-018-2336-0

22. Harring N (2014) Corruption, inequalities and the perceived effectiveness of economic proenvironmental policy instruments: A European cross-national study. Environmental Science \& Policy, 39, 119-128. https://doi.org/110.1016/j.envsci.2013.1008.1011

23. Ike GN, Usman O, Sarkodie SA (2020) Fiscal policy and CO2 emissions from heterogeneous fuel sources in Thailand: evidence from multiple structural breaks cointegration test. Science of The Total Environment, 702, 134711. https://doi.org/134710.131016/j.scitotenv.132019.134711

24. International Energy Agency (IEA) (2021) Database. https://www.iea.org/energyaccess/database/

25. Janssen F, Kunst AE, Mackenbach JP (2006) Association between gross domestic product throughout the life course and old-age mortality across birth cohorts: parallel analyses of seven European countries, 1950-1999. Soc Sci Med 63(1):239-254.

https://doi.org/10.1016/j.socscimed.2005.11.040 
26. Johansen J, Juselius K (1990) Maximum Likelihood Estimation and Inference on Cointegration-with Applications to the Demand for Money. Oxford Bull Econ Stat 52(2):169-210

27. Jorgenson DW, Wilcoxen PJ (1993) Reducing US carbon dioxide emissions: an assessment of different instruments. Journal of Policy Modeling, 15(5-6), 491-520. https://doi.org/410.1016/0161-8938(1093)90003-90009

28. Kan H (2014) Globalisation and environmental health in China. The Lancet 384(9945):721-723. https://doi.org/10.1016/S0140-6736(14)60957-0

29. Katircioglu S, Katircioglu S (2018) Testing the role of fiscal policy in the environmental degradation: the case of Turkey. Environmental Science and Pollution Research, 25(6), 5616-5630. https://doi.org/5610.1007/s11356-11017-10906-11351

30. Kharecha PA, Hansen JE (2013) Prevented mortality and greenhouse gas emissions from historical and projected nuclear power. Environ Sci Technol, 47(9), 4889-4895. https://doi.org/10.1021/es3051197

31. Kim Y-D, Han H-O, Moon Y-S (2011) The empirical effects of a gasoline tax on CO2 emissions reductions from transportation sector in Korea. Energy Policy, 39(2), 981-989. https://doi.org/910.1016/j.enpol.2010.1011.1026

32. Koengkan M, Fuinhas JA, Silva N (2021a) Exploring the capacity of renewable energy consumption to reduce outdoor air pollution death rate in Latin America and the Caribbean region. Environ Sci Pollut Res, 1-19. https://doi.org/10.1007/s11356-020-10503-x

33. Koengkan M, Fuinhas JA, Vieira I (2021b) The Reaction of the Consumption of Fossil Fuels to Trade Openness in Latin America \& the Caribbean Countries. Revista de Estudos Sociais 22(45):1-23. https://doi.org/10.19093/res10861

34. KOF Globalization index (2021) KOF Globalization index. https://www.kof.ethz.ch/en/forecastsandindicators/indicators/kof-globalisation-index.html

35. Kosonen K, Nicodème G (2009) The role of fiscal instruments in environmental policy. CESifo Working Paper Series No. 2719, Available at SSRN: https://ssrn.com/abstract=1437501

36. Lelieveld J, Klingmüller K, Pozzer A, Burnett RT, Haines A, Ramanathan V (2019) Effects of fossil fuel and total anthropogenic emission removal on public health and climate. Proceedings of the National Academy of Sciences, 116(15), 7192-7197. https://doi.org/10.1073/pnas.1819989116

37. Li S-J, Chang T-H, Chang S-L (2017) The policy effectiveness of economic instruments for the photovoltaic and wind power development in the European Union. Renewable Energy, 101, 660-666. https://doi.org/610.1016/j.renene.2016.1009.1005

38. Lin B, Li X (2011) The effect of carbon tax on per capita CO2 emissions. Energy Policy, 39(9), 51375146. https://doi.org/5110.1016/j.enpol.2011.5105.5050

39. Liu M, Huang Y, Jin Z, Ma Z, Liu X, Zhang B, Kinney PL (2017a) The nexus between urbanization and PM2. 5 related mortality in China. Environ Pollut 227:15-23. https://doi.org/10.1016/j.envpol.2017.04.049 
40. Liu M, Huang Y, Ma Z, Jin Z, Liu X, Wang H, Kinney PL (2017b) Spatial and temporal trends in the mortality burden of air pollution in China: 2004-2012. Environment international 98:75-81. https://doi.org/10.1016/j.envint.2016.10.003

41. Liu Z, Mao X, Tu J, Jaccard M (2014) A comparative assessment of economic-incentive and command-and-control instruments for air pollution and $\mathrm{CO} 2$ control in China's iron and steel sector. Journal of Environmental Management, 144, 135-142. https://doi.org/110.1016/j.jenvman.2014.1005.1031

42. López R, Palacios A (2014) Why has Europe become environmentally cleaner? Decomposing the roles of fiscal, trade and environmental policies. Environmental and Resource Economics, 58(1), 91108. https://doi.org/110.1007/s10640-10013-19692-10645

43. Machado JAF, Silva JMCS (2019) Quantiles via Moments. Journal of Econometrics forthcoming. https://doi.org/10.1016/j.jeconom.2019.04.009Get

44. Machol B, Rizk S (2013) Economic value of US fossil fuel electricity health impacts. Environment international 52:75-80. https://doi.org/10.1016/j.envint.2012.03.003

45. Mansoor A, Sultana B (2018) Impact of Population, GDP and Energy Consumption on Carbon Emissions: Evidence from Pakistan Using an Analytic Tool IPAT. Asian Journal of Economics Empirical Research 5(2):183-190. https://doi.org/10.20448/journal.501.2018.52.183.190

46. Mao X, Yang S, Liu Q, Tu J, Jaccard M (2012) Achieving CO2 emission reduction and the co-benefits of local air pollution abatement in the transportation sector of China. Environ Sci Policy, 21. https://doi.org/10.1016/j.envsci.2012.03.010., 1-13

47. Marais EA, Silvern RF, Vodonos A, Dupin E, Bockarie AS, Mickley LJ, Schwartz J (2019) Air quality and health impact of future fossil fuel use for electricity generation and transport in Africa. Environ Sci Technol 53(22):13524-13534. https://doi.org/10.1021/acs.est.9b04958

48. Mukhopadhyay K, Forssell O (2005) An empirical investigation of air pollution from fossil fuel combustion and its impact on health in India during 1973-1974 to 1996-1997. Ecol Econ 55(2):235-250. https://doi.org/10.1016/j.ecolecon.2004.09.022

49. Nordhaus WD (2007) To tax or not to tax: Alternative approaches to slowing global warming. Review of Environmental Economics Policy 1(1):26-44. https://doi.org/10.1093/reep/rem1008

50. Our World in Data (2021) Air pollution. https://ourworldindata.org/air-pollution

51. Pearce D (1991) The role of carbon taxes in adjusting to global warming. The Economic Journal, 101(407), 938-948. https://doi.org/910.2307/2233865

52. Pesaran MH (2004) General diagnostic tests for cross-section dependence in panels. The University of Cambridge, Faculty of Economics. Cambridge Working Papers in Economics, $\mathrm{n}$. 0435.https://doi.org/10.17863/CAM.5113

53. Pesaran MH (2007) A simple panel unit root test in the presence of cross-section dependence. J Appl Econom, 22(2):256-312.https://doi.org/ 10.1002/jae.951

54. Postula M, Radecka-Moroz K (2020) Fiscal policy instruments in environmental protection. Environmental impact assessment review, 84, 106435. 
https://doi.org/106410.101016/j.eiar.102020.106435

55. Qiu R, Xu J, Xie H, Zeng Z, Lv C (2020) Carbon tax incentive policy towards air passenger transport carbon emissions reduction. Transportation Research Part D: Transport and Environment, 85, 102441. https://doi.org/102410.101016/j.trd.102020.102441

56. Rasoulinezhad E, Taghizadeh-Hesary F, Taghizadeh-Hesary F (2020) How is mortality affected by fossil fuel consumption, $\mathrm{CO} 2$ emissions and economic factors in the $\mathrm{CIS}$ region? Energies 13(9):2255. https://doi.org/10.3390/en13092255

57. Ring I (2002) Ecological public functions and fiscal equalisation at the local level in Germany. Ecological Economics, 42(3), 415-427. https://doi.org/410.1016/S0921-8009(1002)00124-00126

58. Rocher CL (2017) Linear and nonlinear relationships between interest rate changes and stock return: International evidence.Universidad de Valencia, Working Paper, 17(16):119:https://www.uv.es/bfc/TFM2017/16\%20Carlos\%20Lopez\%20Rocher.pdf

59. Rumana HS, Sharma RC, Beniwal V, Sharma AK (2014) A retrospective approach to assess human health risks associated with growing air pollution in urbanized area of Thar Desert, western Rajasthan, India. Journal of Environmental Health Science Engineering 12(1):1-9. https://doi.org/10.1186/2052-336X-12-23

60. Salehnia N, Alavijeh NK, Salehnia N (2020) Testing Porter and pollution haven hypothesis via economic variables and $\mathrm{CO} 2$ emissions: a cross-country review with panel quantile regression method. Environ Sci Pollut Res 27(25):31527-31542. https://doi.org/10.1007/s11356-020-09302-1

61. Shahbaz M, Bhattacharya M, Ahmed K (2015) Growth-globalization-emissions nexus: the role of population in Australia. Department of Economics Discussion Paper Series (discussion paper 2315). Monash University Clayton, Austeralia

62. Shahbaz M, Shahzad SJH, Mahalik MK, Hammoudeh S (2018) Does globalisation worsen environmental quality in developed economies? Environmental Modeling Assessment 23(2):141156. https://doi.org/10.1007/s10666-017-9574-2

63. Shmelev SE, Speck SU (2018) Green fiscal reform in Sweden: econometric assessment of the carbon and energy taxation scheme. Renewable and Sustainable Energy Reviews, 90, 969-981. https://doi.org/910.1016/j.rser.2018.1003.1032

64. Stelling P (2014) Policy instruments for reducing CO2-emissions from the Swedish freight transport sector. Research in Transportation Business Management 12:47-54. https://doi.org/10.1016/j.rtbm.2014.1008.1004

65. Taghizadeh-Hesary F, Taghizadeh-Hesary F (2020) The impacts of air pollution on health and economy in Southeast Asia. Energies 13(7):1812. https://doi.org/10.3390/en13071812

66. Vera S, Sauma E (2015) Does a carbon tax make sense in countries with still a high potential for energy efficiency? Comparison between the reducing-emissions effects of carbon tax and energy efficiency measures in the Chilean case. Energy, 88, 478-488. https://doi.org/410.1016/j.energy.2015.1005.1067 
67. Vergara W, Alatorre C, Alves L (2013) Rethinking Our Energy Future A White Paper on Renewable Energy for the 3GFLAC Regional Forum. Publishing Inter-American Development Bank. https://cutt.ly/DxhLZ5m. Accessed 15 March 2021

68. Wang P (2020) China's air pollution policies: progress and challenges. Current Opinion in Environmental Science \& Health, 100227. https://doi.org/100210.101016/j.coesh.102020.100227

69. Wooldridge JM (2002) Econometric analysis of cross-section and panel data. The MIT Press Cambridge, Massachusetts London

70. World Bank Open Data (2021) Database.http://www.worldbank.org/

71. Xie Y, Wu D, Zhu S (2021) Can new energy vehicles subsidy curb the urban air pollution? Empirical evidence from pilot cities in China. Science of The Total Environment, 754, 142232. https://doi.org/142210.141016/j.scitotenv.142020.142232

72. Yuelan P, Akbar MW, Hafeez M, Ahmad M, Zia Z, Ullah S (2019) The nexus of fiscal policy instruments and environmental degradation in China. Environmental Science and Pollution Research, 26(28), 28919-28932. https://doi.org/28910.21007/s11356-28019-06071-28914

73. Zhang J, Zhang J, Lee R (2001) Mortality decline and long-run economic growth. J Public Econ 80(3):485-507. https://doi.org/10.1016/S0047-2727(00)00122-5

74. Zimmer A, Koch N (2017) Fuel consumption dynamics in Europe: Tax reform implications for air pollution and carbon emissions. Transportation Research Part A: Policy Practice 106:22-50. https://doi.org/10.1016/j.tra.2017.1008.1006

\section{Appendix}

Table 1A. Bias-corrected LM-based test

\section{Variables}

\section{LM(k)-stat}

\begin{tabular}{lll}
\hline DRAP & 3.01 & $\star \star \star$ \\
\hline CO2 & 6.40 & $\star \star \star$ \\
\hline REC & 4.73 & $\star \star \star$ \\
\hline EIP & 4.38 & $\star \star \star$ \\
\hline FOC & 6.02 & $\star \star \star$ \\
\hline GDP & 5.14 & $\star \star \star$ \\
\hline URB & 2.88 & $\star \star \star$ \\
\hline KOFSOGI & 7.79 & $\star \star \star$ \\
\hline KOFECGI & 7.34 & $\star \star \star$
\end{tabular}

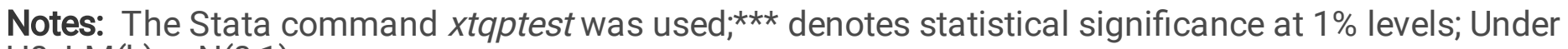
$\mathrm{HO}, \mathrm{LM}(\mathrm{k}) \sim \mathrm{N}(0,1)$. 
Table 2A. VIF-and Pesaran CD-tests

\begin{tabular}{|c|c|c|c|c|c|}
\hline Variables & VIF & $1 / \mathrm{VIF}$ & Mean VIF & CD-test & p-value \\
\hline DRAP & N.A & & 5.06 & 10.99 & $\star \star \star$ \\
\hline $\mathrm{CO} 2$ & 8.45 & 0.1183 & & 32.37 & $\star \star \star *$ \\
\hline REC & 2.31 & 0.4324 & & 24.16 & $\star \star \star *$ \\
\hline EIP & 1.89 & 0.5285 & & 42.49 & $\star \star \star *$ \\
\hline FOC & 15.68 & 0.0637 & & 50.39 & 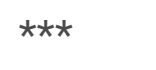 \\
\hline GDP & 1.65 & 0.6070 & & 50.89 & $\star \star \star *$ \\
\hline URB & 4.43 & 0.2258 & & 45.94 & $\star * *$ \\
\hline KOFSoGI & 4.40 & 0.2271 & & 56.71 & $\star * *$ \\
\hline KOFEcGI & 1.67 & 0.5991 & & 26.10 & $\star \star \star \star ~$ \\
\hline
\end{tabular}

NotesThe commands vif and $x t c d$ of Stata were used; $* \star \star$ denotes statistical significance at $1 \%$ levels; N.A denotes not available.

Table 4A. Hausman test

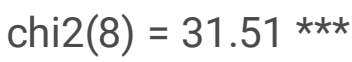

Notes: The Stata command hausman (with the options sigmamore) was used;*** denotes statistically significant at the $1 \%$ level; Hausman results for $\mathrm{H}_{0}$ : difference in coefficients not systematic.

\section{Figures}




\begin{tabular}{|c|c|c|c|c|c|}
\hline \multirow[t]{3}{*}{ Variables } & \multicolumn{5}{|c|}{ Panel Unit Root test (CIPS) (Zt-bar) } \\
\hline & \multicolumn{3}{|c|}{ Without trend } & \multicolumn{2}{|c|}{ With trend } \\
\hline & Lags & Zt-bar & & \multicolumn{2}{|l|}{ Zt-bar } \\
\hline DRAP & 1 & 2.107 & & \multicolumn{2}{|l|}{-0.767} \\
\hline $\mathrm{CO} 2$ & 1 & -4.009 & $\star \star \star$ & -2.076 & $\star \star$ \\
\hline REC & 1 & -2.051 & ** & \multicolumn{2}{|l|}{0.136} \\
\hline EIP & 1 & -2.636 & $\star \star \star$ & -3.072 & *** \\
\hline FOC & 1 & -3.530 & $\star \star \star ~$ & -2.182 & *** \\
\hline GDP & 1 & 1.653 & & \multicolumn{2}{|l|}{1.777} \\
\hline URB & 1 & -2.341 & $\star \star \star ~$ & \multicolumn{2}{|l|}{0.456} \\
\hline KOFSOGI & 1 & -3.182 & $\star \star \star ~$ & \multicolumn{2}{|l|}{-1.274} \\
\hline KOFEcGI & 1 & -1.199 & & \multicolumn{2}{|l|}{-0.743} \\
\hline \multicolumn{6}{|c|}{$\begin{array}{l}\text { Notes: The Stata command multipurt was used; The null for CIPS test is: series have unit root; the lag } \\
\text { length (1) and trend were used in this test; } * \star *, * \star \\
\text { denotes statistically significant at } 1 \% \text { and } 5 \% \text { level. }\end{array}$} \\
\hline
\end{tabular}




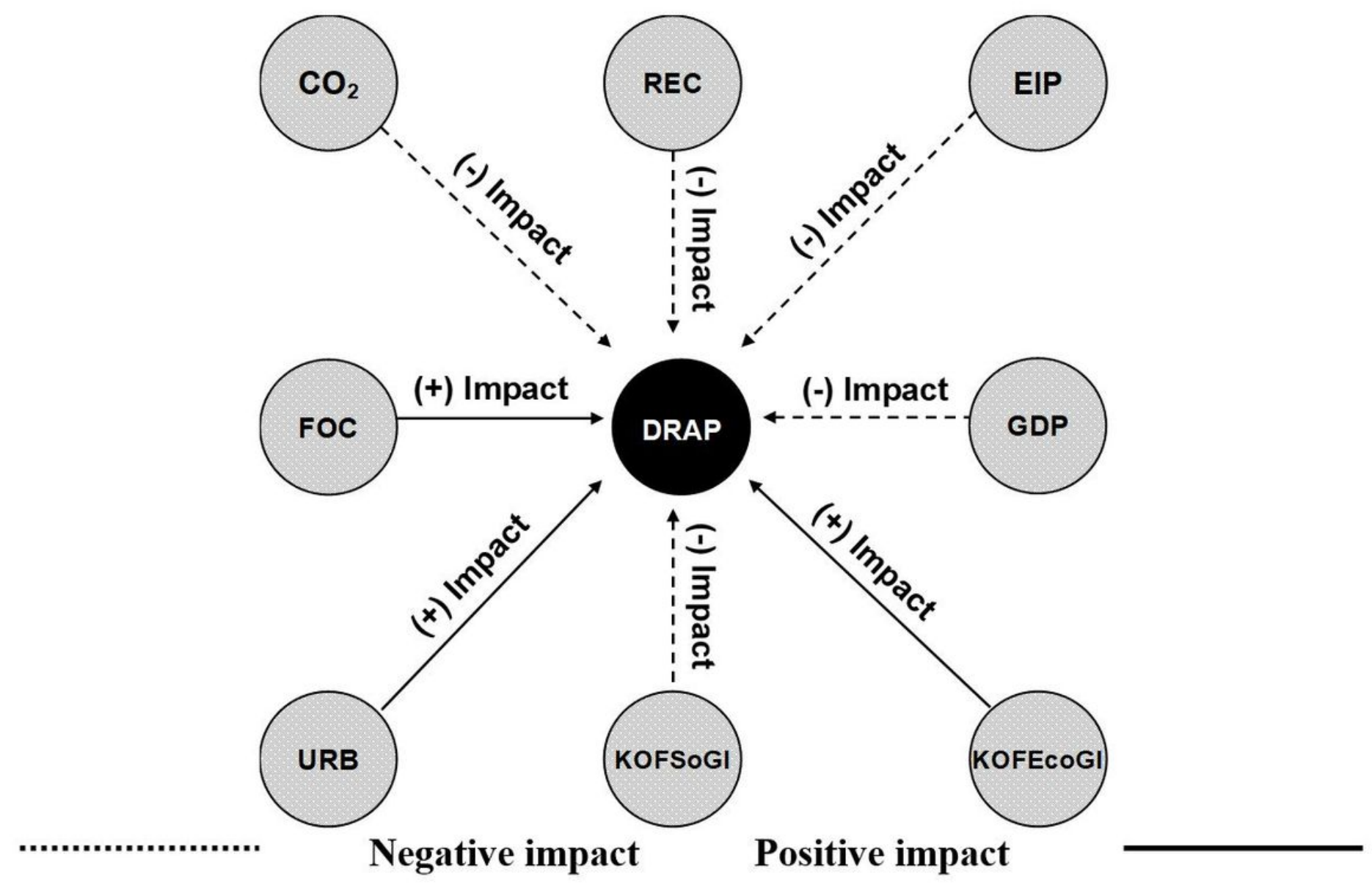

Figure 1

Summary of the variable's effect. This figure was created by the authors. 